\title{
MORBILI PADA ANAK DALAM PENGOBATAN ANTI RETRO VIRAL (ARV)
}

\author{
Bagus Agung Surya Dipta Nugraha
}

Program Studi Pendidikan Dokter, Fakultas Kedokteran Universitas Udayana

\begin{abstract}
ABSTRAK
Pendahuluan: Morbili adalah penyakit infeksi virus akut menular yang disebabkan oleh virus morbili. Morbili merupakan penyakit infeksi virus akut menular yang ditandai dengan 3 stadium yaitu : stadium kataral, stadium erupsi dan stadium konvalesensi. Nama lain morbili adalah campak, measles, atau rubeola.Morbili disebabkan oleh virus yang tergolong Famili Paramyxovirus, yaitu genus virus morbili yang terdapat dalam sekret nasofaring dan darah selama masa prodromal sampai 24 jam setelah timbul bercak-bercak.

Kasus: Pasien laki-laki, 6 tahun, beragama Hindu, Suku Bali, datang dengan keluhan panas badan sejak 5 hari yang lalu. Panas badan tidak diukur dengan termometer. Panas dirasakan naik turun, membaik dengan obat penurun panas. Keluhan timbul bintik merah dirasakan sejak 1 hari yang lalu. Awalnya bintik merah ditemukan muncul di daerah leher kemudian ke wajah dan dada. Timbulnya bintik merah disertai dengan rasa gatal dan panas. Keluhan ini disertai dengan mimisan 1 hari yang lalu, batuk berdahak sejak 5 hari yang lalu dan mata merah sejak 1 hari yang lalu. Pasien baru pertama kali merasakan keluhan seperti ini. Memiliki riwayat pemakaian ARV rutin sejak usia 1,5 tahun.
\end{abstract}

Kata Kunci: ruam, morbili, HIV, ARV.

\section{MEASLES IN CHILDREN WITH ANTI RETRO VIRAL (ARV) ON TREATMENT}

\begin{abstract}
Introduction: Morbili is an acute viral infectious disease caused by a virus transmitted morbili. Morbili is a contagious acute viral infectious disease that is characterized by three stages: catarrhal stage, eruption stage and convalence stage. Another name morbili is measles, measles, or rubeola. Morbili caused by a virus that is classified as Family paramyxovirus, the virus genus morbili contained in nasopharyngeal secretions and blood during the prodromal period until 24 hours after the onset of spots.

Case: Patient male, 6 years old, Hindu, Balinese tribe, came with complaints of febris since 5 days ago. Febris is not measured with a thermometer. The heat is felt up and down, getting better with medicine. Complaints red spots felt since 1 day ago. Originally discovered red spots appear in the neck area and then to the face and chest. The incidence of rash accompanied by itching and heat. This complaint is accompanied with nosebleeds 1 day ago, cough with sputum since 5 days ago and the red eye from one day ago. Patients feel the first time such complaints. Having a history of antiretroviral use regularly since 1.5 years old.
\end{abstract}

Keywords: rash, morbili, HIV, antiretroviral drugs.

\section{PENDAHULUAN}

Morbili adalah penyakit infeksi virus akut menular yang disebabkan oleh virus morbili. Biasanya penyakit ini timbul pada masa anak dan kemudian menyebabkan kekebalan seumur hidup. Morbiditas dan mortalitas pada negara berkembang lebih karena faktor malnutrisi dan infeksi sekunder.Walaupun penyakit morbili jarang muncul disebabkan oleh program 
imunisasi yang berjalan dengan baik, pengenalan terhadap penyakit ini perlu diketahui terutama untuk mencegah komplikasi lebih lanjut.

Morbili merupakan penyakit infeksi virus akut menular yang ditandai dengan 3 stadium yaitu : a. stadium kataral, b. stadium erupsi dan c. stadium konvalesensi. Nama lain morbili adalah campak, measles, atau rubeola. ${ }^{1}$ Morbili disebabkan oleh virus yang tergolong Famili Paramyxovirus, yaitu genus virus morbili yang terdapat dalam sekret nasofaring dan darah selama masa prodromal sampai 24 jam setelah timbul bercak-bercak. ${ }^{2}$ Virus ini tidak tahan panas tetapi dapat terawetkan dalam jangka waktu lama dalam suhu rendah. $^{3}$ Sumber lain menyebutkan virus ini dapat dihancurkan oleh asam, sinar intensitas tinggi, dan pengeringan namun dapat bertahan beberapa jam dalam droplet. ${ }^{3,4}$

Attack rate virus morbili sekitar $90 \%$ pada individu yang rentan. ${ }^{4,5}$ Kerentanan terhadap virus morbili tidak tergantung umur. ${ }^{4}$ Bayi yang dilahirkan oleh ibu yang pernah menderita morbili akan mendapat kekebalan secara pasif (melalui plasenta) sampai umur 4-6 bulan dan setelah umur tersebut kekebalan akan mengurang sehingga si bayi dapat menderita morbili. ${ }^{1,5}$

Morbiditas dan mortalitas pada negara berkembang cenderung karena faktor malnutrisi dan infeksi sekunder. Riwayat kontak dengan pasien morbili/curiga morbili mungkin tidak ada karena penyebaran lewat udara yang efektif dan pasien yang sangat menular selama masa prodromal. ${ }^{6}$

Masa inkubasi 10-20 hari. $^{1}$ Ditandai dengan 3 stadium yaitu : a. stadium kataral, b. stadium erupsi dan c. stadium konvalesensi.

Stadium kataral berlangsung selama 4-5 hari disertai panas, malaise, batuk, fotofobia, konjungtivitis dan coryza. Konjungtivitis menyebabkan edema palpebra, lakrimasi, dan fotofobia. ${ }^{3}$ Injeksi linear pada batas kelopak mata bawah yang disebut Stimson line timbul sebelum injeksi yang lebih luas menutupi tanda tersebut. ${ }^{3}$ Menjelang akhir stadium kataral dan 24 jam sebelum timbul enantema, timbul bercak Koplik yang patognomonik bagi morbili, tetapi sangat jarang dijumpai. ${ }^{1,3,5}$ Bercak Koplik berwarna putih kelabu, sebesar ujung jarum dan dikelilingi oleh eritema. Lokalisasinya di mukosa bukalis berhadapan dengan molar bawah. ${ }^{1,3,4,6}$ Jarang ditemukan di bibir bawah tengah atau palatum. Kadang-kadang terdapat makula halus yang kemudian menghilang sebelum stadium erupsi. Gambaran darah tepi adalah limfositosis dan leukopenia. ${ }^{1}$

Secara klinis gambaran penyakit menyerupai influenza dan sering didiagnosis sebagai influenza. Diagnosis perkiraan yang besar dapat dibuat bila ada bercak Koplik dan penderita pernah kontak dengan penderita morbili dalam waktu 2 minggu terakhir. ${ }^{1}$

Pada Stadium erupsi, Coryza dan batuk-batuk bertambah. Timbul enantema atau titik merah di palatum durum dan palatum mole. Kadang-kadang terlihat pula bercak Koplik. ${ }^{1}$ Ruam makulopapular berbatas tegas muncul ketika gejala saluran napas mencapai puncak dan lesi ini cepat menyebar. Terjadinya eritema yang berbentuk makula-papula disertai menaiknya suhu badan. Puncak demam terjadi saat eritema/ruam muncul dan turun 2-3 hari kemudian. ${ }^{6}$ Puncak demam dapat diikuti oleh iritabilitas, somnolen, dan delirium yang bersifat sementara. ${ }^{3} \mathrm{Di}$ antara makula terdapat kulit yang normal. Mula-mula eritema timbul di belakang telinga, di bagian atas lateral tengkuk, sepanjang rambut dan bagian belakang bawah. Kadang-kadang terdapat perdarahan ringan pada kulit. Rasa gatal, muka bengkak. Ruam mencapai anggota bawah pada hari ketiga dan akan menghilang dengan urutan seperti terjadinya. ${ }^{1,4}$ Saat lesi ini melibatkan ekstremitas lesi ini pudar mulai dari wajah dan menghilang secara lengkap dalam waktu 6 hari.Berikut gambaran ruam pada morbili.

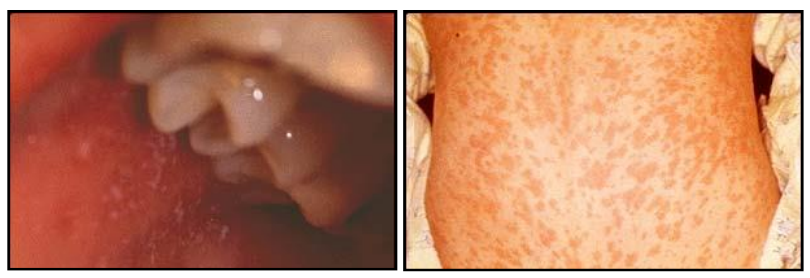

Gambar 1a. Bintik Koplik ${ }^{7}$ dan 1b. Ruam pada morbili ${ }^{8}$

Terdapat pembesaran kelenjar getah bening di sudut mandibula dan di daerah leher belakang. Pula terdapat sedikit splenomegali. ${ }^{1,3}$ Tidak jarang disertai diare dan muntah.Variasi dari morbili yang biasa ini adalah black measles yaitu morbili yang disertai perdarahan pada kulit, mulut, hidung dan traktus digestivus. ${ }^{1,3}$

Pada Stadium konvalesensi, erupsi berkurang meninggalkan bekas yang berwarna lebih tua (hiperpigmentasi) yang lama kelamaan akan hilang sendiri. Hiperpigmentasi ini merupakan gejala 
patognomonik untuk morbili. Pada penyakit-penyakit lain dengan eritema atau eksantema ruam kulit menghilang tanpa hiperpigmentasi. Selain hiperpigmentasi pada anak Indonesia sering ditemukan pula kulit yang bersisik. Kulit bersisik tidak terjadi pada telapak tangan dan kaki. ${ }^{4}$ Suhu menurun sampai menjadi normal kecuali bila ada komplikasi.

Demam tinggi dan letargi menonjol pada penyakit morbili. ${ }^{6}$ Pasien bersifat menular sejak masa prodromal hingga 5 hari setelah ruam. ${ }^{4}$ Pada bayi yang masih memiliki antibodi maternal dan individu yang menerima imunoglobulin penyakit morbili yang terjadi disebut modified measles di mana gambaran-gambaran karakteristik dari morbili klasik sedikit yang timbul, severitas penyakit lebih rendah, dan perjalanan penyakit lebih singkat. Varian lain dari morbili adalah atypical measles ruam timbul secara periferal dan berhubungan dengan demam tinggi, pneumonia, efusi pleura yang jarang, dan hepatitis. Ruam pada varian ini bersifat petechiae atau vesikuler. Ini mungkin disebabkan respon host yang abnormal, di mana terbentuk titer antibodi morbili yang sangat tinggi.

Karakteristik dari pemeriksaan laboratorium adalah limfopenia. 5,6 Leukosit total dapat turun hingga 1500/ $\mu$ L. $^{6}$ Metode cepat yang berguna misalnya dengan deteksi langsung antigen morbili dengan antibodi fluoresen terhadap pengecatan sel-sel nasofaring. Tes PCR dari sekresi orofaring dari urin sangat sensitif dan spesifik dan dapat mendeteksi infeksi hingga 5 hari sebelum gejala. ${ }^{6}$

Urutan teratur dari gejala prodromal, bintik Koplik, dan ruam menyeluruh dapat membentuk diagnosis klinik dengan reliabilitas yang tinggi. Isolasi virus dan studi antibodi tidak diperlukan. ${ }^{3}$

Penyakit campak dibedakan dari diagnosis lain sepertiGerman measles, Eksantema subitum (roseola), sensitivitas terhadap obat, Infectious mononucleosis.

Penyakit German measlesdisebabkan Rubivirus. Masa inkubasi 14-21 hari. ${ }^{9}$ Pada penyakit ini tidak ada bercak Koplik, tetapi ada pembesaran kelenjar di daerah suboksipital, servikal bagian posterior, belakang telinga. ${ }^{1,3,9}$ lesi timbul pada wajah yang menyebar ke badan dan ekstremitas, berwarna pink atau merah terang dan menghilang setelah tiga hari. ${ }^{9}$ Severitas penyakit oleh rubella lebih rendah dan tanpa batuk. ${ }^{3}$

Eksantema subitum (roseola) disebabkan oleh Human Herpes Virus tipe 6. Ditandai dengan demam tinggi mendadak mencapai $40-40,6^{\circ} \mathrm{C}$. Anak tampak iritabel biasanya disertai koriza, konjungtivitis, dan batuk. Demam menetap 3-5 hari dan turun mendadak ke suhu normal. ${ }^{9}$ Ruam akan timbul bila suhu badan menjadi normal. ${ }^{1,3}$ ruam tampak pertama kali di punggung, dan menyebar ke leher ekstremitas atas, muka, dan ekstremitas bawah. ${ }^{9}$

Sensitivitas terhadap obat. Ruam yang timbul karena sensitivitas obat antara lain barbiturat, hidantoin, penisilin, dan sulfonamid. ${ }^{3}$

Infectious mononucleosis. Dapat dibedakan dari morbili berdasarkan hasil lab darah lengkap. ${ }^{3}$ Pemulihan biasanya terjadi 7-10 hari setelah onset gejala. Terapi bersifat simtomatik yaitu antipiretika (asetaminofen, kompres hangat, hindari salisilat) bila suhu badan tinggi, pemeliharaan kesehatan mata, sedativum, obat batuk (hindari penekan opioid) dan memperbaiki keadaan umum. Tindakan lain ialah pengobatan segera terhadap komplikasi yang timbul. ${ }^{1,6}$ Infeksi bakteri sekunder harus ditangani dengan tepat. Antibiotik profilaksis tidak diindikasikan. Ribavirin bersifat aktif in vitro dan dapat digunakan pada anak dengan sistem imun tertekan. ${ }^{6}$ Tapi sumber lain menyebutkan ribavirin tidak memiliki efek pada pasien tersebut. ${ }^{4}$ Ribavirin intravena dosis tinggi dikombinasi dengan interferon- $\alpha$ intratekal dapat digunakan pada manajemen SSPE. Pada anak dengan malnutrisi dapat diberikan suplementasi vitamin A dapat diberikan. ${ }^{6}$ Vitamin A diberikan secara oral dengan dosis sekitar 100.000 IU pada bayi umur 6 bulan - 1 tahun dan 200.000 IU pada anak yang lebih tua.

\section{KASUS}

Pasien laki-laki, 6 tahun, beragama Hindu, Suku Bali, datang dengan keluhan panas badan sejak 5 hari yang lalu. Panas badan tidak diukur dengan termometer. Panas dirasakan naik turun, membaik dengan obat penurun panas. Riwayat menggigil dan kejang saat demam disangkal.

Keluhan timbul bintik merah dirasakan sejak 1 hari yang lalu. Awalnya bintik merah ditemukan muncul di daerah leher kemudian ke wajah dan dada. Timbulnya bintik merah disertai dengan rasa gatal dan panas.

Keluhan ini disertai dengan mimisan 1 hari yang lalu , batuk berdahak sejak 5 hari yang lalu dan mata merah sejak 1 hari yang lalu. 
BAB dan BAK (+) normal, terakhir pada pagi hari sebelum masuk rumah sakit, konsistensi normal. Makan dan minum dikatakan baik.

Pasien baru pertama kali merasakan keluhan seperti ini. Dengan riwayat pemakaian ARV rutin sejak usia 1,5 tahun. Pasien sempat berobat ke poli anak 2 hari SMRS mendapat obat Sanmol dan Trimoxsul.

Tidak ada anggota keluarga yang mengalami keluhan yang sama dengan pasien.Riwayat penyakit sistemik seperti hipertensi, DM, jantung, dan asma disangkal.Orang tua pasien sudah dengan pengobatan ARV rutin.

Riwayat persalinan. Pasien lahir normal, ditolong oleh dokter, dengan berat badan lahir 2700 gram, panjang badan 47 sentimeter, segera menangis. Kelainan kongenital tidak ada.Riwayat imunisasi :BCG sebanyak 1 kali. Hepatitis B sebanyak 4 kali, Polio sebanyak 4 kali, DPT sebanyak 3 kali,Campak sebanyak 1 kali.

Pasien diberikan ASI pada usia 0 - 3 bulan, dengan tambahan susu formulasejak usia 0 bulan. Mulai usia 6 bulan diberikan bubur susu. Diberikan nasi tim sejak usia 12 bulan.

Pada riwayat tumbuh kembang, pasien menegakkan kepala pada umur 3 bulan, membalikkan badan pada usia 4 bulan, duduk pada usia 6 bulan, merangkak pada usia 8 bulan, berdiri pada 10 bulan, berjalan pada usia 12 bulan, berbicara pada usia 12 bulan.

Pada pemeriksaan fisik, keadaan umum lemah, laju nafas 20 kali per menit, nadi 108 kali per menit, suhu aksila $38^{\circ} \mathrm{C}$. Berat badan 18 kilogram ( berat badan ideal $20 \mathrm{~kg}$ ) dengan waterlow 90\% ( gizi baik ).

Pada status generalis ditemukan mata hiperemis dekstra et sinistra, sekret mata dekstra et sinistra. Sekret hidung (+). Faring hiperemis, lidah kotor, tidak ditemukan koplik spot. Tidak ada kaku kuduk dan pembesaran kelenjar getah bening. Jantung dan pulmo dalam batas normal. Pada kulit ditemukan makula eritema pada area wajah leher dan badan.

Pada pemeriksaan darah lengkap, didapatkan kadar WBC 9,47 x $10^{3} \mathrm{~K} / \mu \mathrm{L}$, Neutrofil 62,85\%, Limfosit 20,91\%, Hemoglobin 12,32 g/dL, Hematokrit 37,2 \%, Platelet 198,4 x 105 k/Ml, CRP 34,2.

Pasien didiagnosis kerja dengan Morbili + infeksi HIV (on treatment) + gizi baik. Dengan penatalaksanaan rawat inap di ruangan isolasi, kebutuhan cairan $1400 \mathrm{cc} /$ hari $\rightarrow$ mampu minum 400 $\mathrm{cc} /$ hari $\rightarrow$ IVFD D5 $1 / 2$ NS $1000 \mathrm{~mL}$ per hari $\rightarrow 12$ tetes makro/menit. Kebutuhan kalori 1440 kkal/hari. Kebutuhan protein 18 gram. Vitamin A 200.000 IU per oral 1 kali. Paracetamol sirup 1,5 cth jika demam. Ambroxol 0,5mg/kgBB/hari 9mg/hari $3 \mathrm{mg}$ setiap 8jam. Anti Retro Viral dilanjutkan.

\section{DISKUSI}

Morbili adalah penyakit infeksi virus akut menular yang ditandai dengan 3 stadium yaitu stadium kataral, stadium erupsi dan stadium konvalesensi. Gejala klinis terjadi setelah masa inkubasi selama 10-20 hari yang dibagi dalam 3 stadium, yaitu: ${ }^{1}$

1. Stadium kataral (prodromal) berlangsung selama 4-5 hari disertai panas, malaise, batuk, fotofobia, konjungtivitis dan coryza. Menjelang akhir stadium kataral dan 24 jam sebelum timbul enantema, timbul bercak koplik yang patognomonik bagi morbili, tetapi sangat jarang dijumpai. Gambaran darah tepi adalah limfositosis dan leukopenia. ${ }^{1,3}$

2. Stadium erupsi ditandai dengan timbulnya ruam makulopapular berbatas tegas disertai menaiknya suhu badan dan turun 2-3 hari kemudian. Puncak demam dapat diikuti oleh iritabilitas, somnolen, dan delirium yang bersifat sementara. Mula-mula eritema timbul di belakang telinga, di bagian atas lateral tengkuk, sepanjang rambut dan bagian belakang bawah. Kadang-kadang terdapat perdarahan ringan pada kulit. Rasa gatal, muka bengkak. Saat lesi ini melibatkan ekstremitas lesi ini pudar mulai dari wajah dan menghilang secara lengkap dalam waktu 6 hari.Terdapat pembesaran kelenjar getah bening di sudut mandibula dan di daerah leher belakang. ${ }^{1,3}$

3. Stadium konvalesensi ditandai dengan ruam yang mencapai anggota bawah pada hari ketiga dan akan menghilang dengan urutan seperti terjadinya. Erupsi berkurang meninggalkan bekas yang berwarna lebih tua (hiperpigmentasi) yang lama kelamaan akan hilang sendiri. ${ }^{4}$

Pada kasus ini pasien didiagnosis sebagai morbili berdasarkan anamnesis, pemeriksaan fisik dan pemeriksaan penunjang yang didapatkan. Pada anamnesis pasien datang dengan keluhan keluhan panas badan sejak 5 hari yang lalu, naik turun, membaik dengan obat penurun panas. Riwayat menggigil dan kejang saat demam disangkal. Keluhan timbul bintik 
merah dirasakan sejak 1 hari yang lalu, ditemukan awalnya di leher kemudian ke wajah dan dada. Timbulnya bintik merah disertai dengan rasa gatal dan panas. Pasien juga mengeluhkan mimisan 1 hari yang lalu, batuk berdahak sejak 5 hari yang lalu dan mata merah sejak 1 hari yang lalu.BAB dan BAK (+) normal, terakhir pada pagi hari sebelum masuk Rumah Sakit, konsistensi normal. Makan dan minum dikatakan baik. Pada pemeriksaan fisik didapatkan status present temperatur aksila $38{ }^{\circ} \mathrm{C}$, pada mata didapatkan hiperemis $+/+$, sekret $+/+$. Pemeriksaan THT pada faring hiperemis, tanpa pembesaran tonsil. Lidah kotor namun tidak didapatkan koplik spot. Pada kulit didapatkan makula eritema di wajah, leher dan badan. Hasil pemeriksaan laboratorium didapatkan dalam batas normal.

Diagnosis banding pada kasus ini yaitu rubella dimana lesi muncul pada wajah yang menyebar ke badan dan ekstremitas yang menghilang setelah tiga hari. Terdapat pembesaran kelenjar di daerah suboksipital, servikal bagian posterior, atau belakang telinga. Warna lesinya merah terang dan lebih terang daripada lesi pada campak. ${ }^{1,3,9}$ Diagnosis banding lain yakni eksantema subitum (roseola) dimana manifestasi klinis yang dapat ditemukan yaitu demam tinggi mendadak, mukosa faring meradang dan adanya coryza. ${ }^{1,3,9}$ Namun yang membedakan dengan morbili yaitu ruam biasanya muncul pada saat suhu tubuh kembali normal dan menghilang dalam 3 hari. Pemeriksaan laboratorium terdapat kenaikan neutrofil pada hari pertama demam, kemudian pada hari ke 3-4 terjadi leukopenia, neutropenia, dan limfositosis.

Terapi pada morbili bersifat simtomatik yaitu dengan pemberian antipiretika (asetaminofen, kompres hangat, hindari salisilat) bila suhu badan tinggi, pemeliharaan kesehatan mata, sedativum, obat batuk (hindari penekan opioid) dan memperbaiki keadaan umum. Tindakan lain ialah pengobatan segera terhadap komplikasi yang timbul. ${ }^{1,6}$ Pada anak dengan malnutrisi dapat diberikan suplementasi vitamin A dapat diberikan.Vitamin A diberikan secara oral dengan dosis sekitar 100.000 IU pada bayi umur 6 bulan -1 tahun dan 200.000 IU pada anak yang lebih tua. Pada kasus ini pasien MRS dan diberikan IVFD D5 1/2 NS $1000 \mathrm{~mL}$ per hari (12 tetes makro/menit), obat antipiretik paracetamol sirup $1 \frac{1}{2}$ cth jika demam $\geq 38,5^{\circ} \mathrm{C}$, ambroxol 3mg setiap 8jam, vitamin A 200.000 IU per oral dan lanjut ARV.

\section{DAFTAR PUSTAKA}

1. Staf Pengajar Ilmu Kesehatan Anak Fakultas Kedokteran Universitas Indonesia (1985), "Infeksi", dalam: Buku Kuliah Ilmu Kesehatan Anak jilid 2, Bagian Ilmu Kesehatan Anak Fakultas Kedokteran Universitas Indonesia, Jakarta, hal. 624-628

2. Pedoman Pelayanan Medis Kesehatan Anak. Bagian Ilmu Kesehatan Anak Fakultas Kedokteran Universitas Udayana Rumah Sakit Umum Pusat Sanglah Denpasar : 2011

3. Rudolph, A.M. (1991), "Bacterial and Viral Infections", dalam: Rudolph's Pediatrics, $19^{\text {th }}$ ed, Appleton \& Lange, Connecticut, hal. 676-680

4. Khuri-Bolos (2001), "Measles", dalam: Elzouki, A.Y., Harfi, H.A., Nazer, H. (eds), Textbook of Clinical Pediatrics, Lippincott Williams \& Wilkins, Philadelphia, hal. 381-383

5. Maldonado, Y. (2004), "Measles", dalam: Behrman, R.E., Kliegman, R.M., Jenson, H.B. (eds), Nelson Textbook of Pediatrics, $17^{\text {th }}$ ed, Saunders, Philadelphia, hal. 1026-1031

6. Hay Jr., W.W., Levin, M.J., Sondheimer, J.M., Deterding, R.R. (2003), "Infections: Viral and Ricketsial", dalam: Current Pediatric Diagnosis \& Treatment, $17^{\text {th }}$ ed, McGraw-Hill, USA, hal. 11631165

7. Anon. (2006-last update), "Measles, Koplik spotsclose-up", dalam: Medline Plus, terdapat: http://www.nlm.nih.gov/medlineplus/ency/imagep ages/2558.htm (Akses: 20 Desember 2014)

8. Anon. (2006-last update), "Measles on the back", dalam: Medline Plus, terdapat: http://www.nlm.nih.gov/medlineplus/ency/imagep ages/2943.htm (Akses: 20 Desember 2014)

9. Rahayu T, Tumbelaka AR. Gambaran Klinis Penyakit Eksantema Akut pada Anak. 2002. Sari Pediatri vol.4;3. pp.104-13. 